\title{
Darier White disease
}

\author{
Amatya $A^{1}$, Karn $D^{1}$, Aryal $E^{1}$, Makaju $R^{2}$, Shakya $A^{3}$, Priyadarshinee $A^{4}$
}

${ }^{1}$ Lecturer, Department of Dermatology and Venereology, Dhulikhel Hospital, KUTH, Dhulikhel, Kavre.

${ }^{2}$ Assistant Professor, Department of Pathology, Dhulikhel Hospital, KUTH, Dhulikhel, Kavre.

${ }^{3}$ Lecturer, Department of Pathology, Dhulikhel Hospital, KUTH, Dhulikhel, Kavre

${ }^{4}$ Intern, Department of Dermatology, Dhulikhel Hospital, KUTH, Dhulikhel, Kavre.

\section{Correspondence}

Dr. Amit Amatya

Department of Dermatology and Venereology,

Dhulikhel Hospital, KUTH,

Dhulikhel, Kavre.

E-mail : dr.amit.amatrya@gmail.com

\section{Introduction}

Darier's disease is an autosomal dominant condition characterized by a per sistent eruption of hyperkeratotic papules, histological examina- tion of which shows suprabasal acantholysis with a distinctive overlying dyskeratosis. Sporadic cases are common. It has worldwide distribution. ${ }^{1}$

\section{Case Report}

A 27 years old gentleman presented with yellow-brown greasy crusted lesions over his face, chest, and back and buttocks. He noticed the leisons for the first time at the age of 12 years. Initially the leisons were few and was present over the forehead only.' later it progresed over to the face, retroauricular areas and chest. The leisons were asymtomatic but was often complicated by seconday infecions.

\begin{abstract}
Darier's disease was described inependently by Darier and White in 1989 AD. Reported prevalence varies from 1/100,000 in Denmark to 1 in 30- 35,000 in northern England and Scotland..$^{1}$ Darier's disease has been reported from other parts of the world, however,there has been no reported cases in Nepal.

It is an inherited autosomal dominat disease characterized by dark crusty lesions over the seborrheic areas of the skin. We are reporting a case of Darier's disease in a Nepalese patient who developed skin leison's over his face and body at the age of 12 years. We took skin punch biopsy from the leisons, which showed findings suggestive of Darier's disease. Our case was treated with isotrerenoin and topical keratolytics. He responded with the given treatment within two weeks of therapy.
\end{abstract}

He visited various health facilities for this problem, where secondary infection was treated, but the leisons did not disappeared.

On examination firm rough papules, which was yellowbrown to skin coloured, it was present on the forehead, scalp, temporal regions and margin of the scalp, nasolabial folds, ears, chest, back and buttocks (Figure 1). There were large warty lesions on behind the pinna as well. Nail changes revealed red and white longitudinal bands of varying width with pathogomonic notch at the free margin of the nail (Figure 2). However, there were no lesions on the mucosal layers, palm and soles.. Laboratory evaluation of renal and liver function tests, hematology, lipid profile and random blood sugar were within the normal limits. A skin punch biopsy was taken from a lesion over the chest. Histopathological examination revealed areas of hyperkeratosis and suprabasal clefts with irregular upward proliferation of papillae, which 


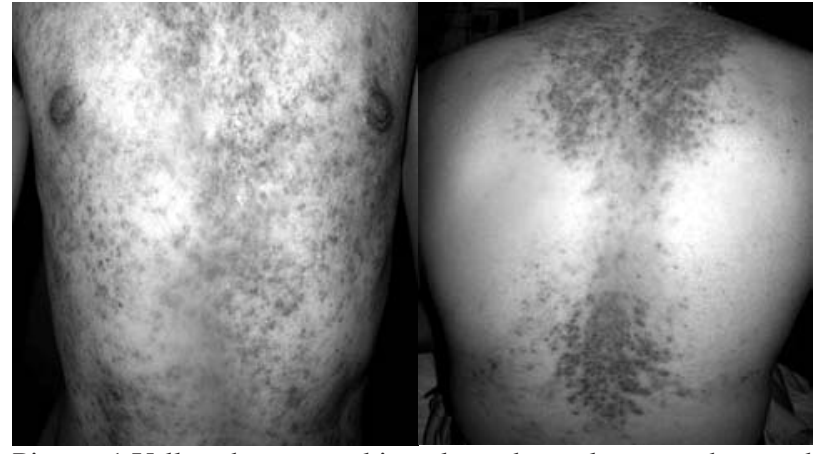

Picture 1 Yellow-brown to skin coloured papules over chest and back
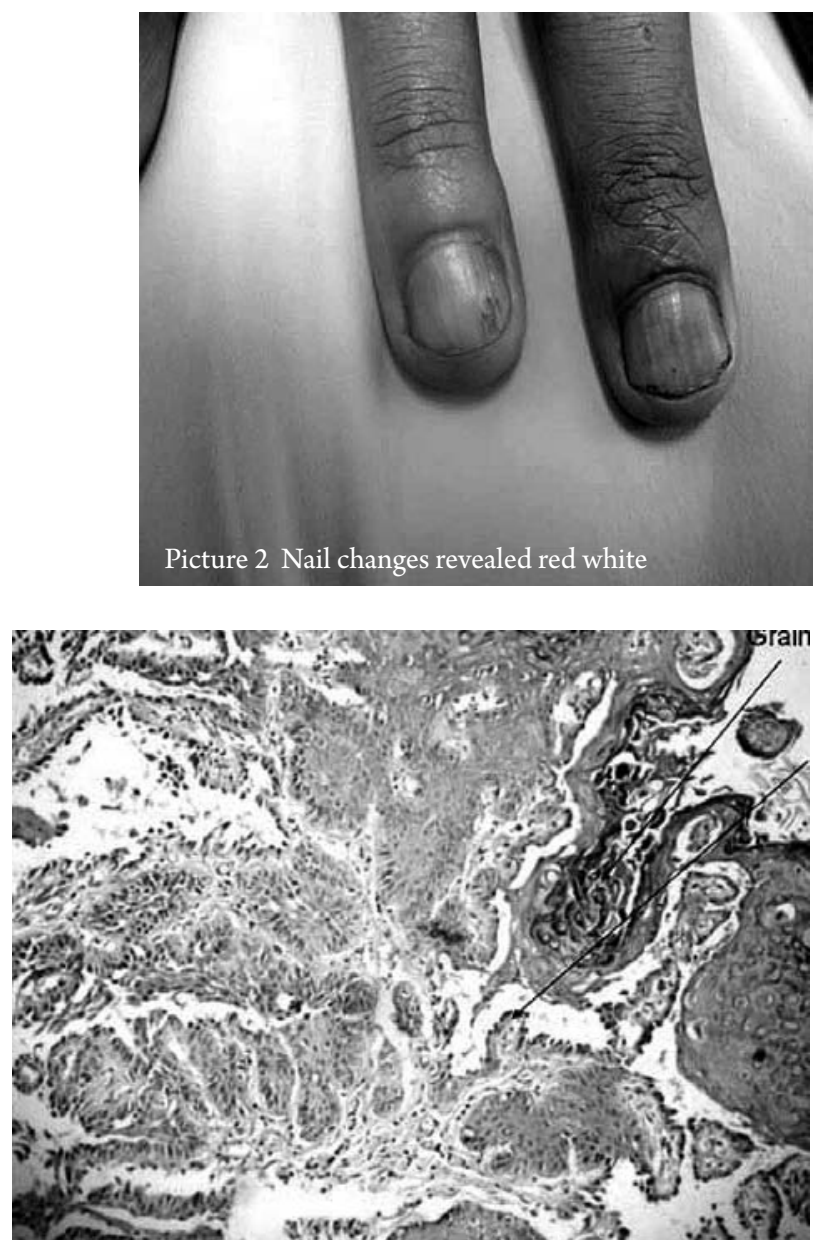

Picture 3 Histopathology showing areas of longitudinal bands of varying width hyperkeratosis and suprabasal clefts with pathogomonic notch at the free with irregular upward proliferation of marginof the nail papillae.

were lined by single layer of basal cells (Figure 3).The histopathology confirmed the diagnosis of Darier's disease. The Patient was treated with isotretinoin $20 \mathrm{mg}$ OD, omeprazol 20mg OD, 5\% salicylic acid\& 3\%coal tar shampoo,sunscreen and azithromycin for 3 days(for secondary infection). Within two weeks of therapy, the leisons were flattened and crusted leisons were reduced. Renal Function Tests, Liver Function Tests and lipid profile was done regularly every month.

\section{Discussion}

Though Darier's disease an inherent autosomal dominant disease, in $47 \%$ cases, there is no clear family history.These patients may have sporadic diseae or family member with milder form of disease.

The first skin leisons are present during teenage and are pruritic. They are exacerbated by heat, sweat, humidity, sunlight, UVB exposure,lithium, oral corticosteroids, and mechanical trauma.

Darier's disease is caused by the disruption of desmosomal junction, which allows entry of adhesion proteins into the acantholytic cells. ${ }^{2,3}$ Aetiology of darier disease is though to be due to mutations in the ATP2A2 gene at chromosome 12q24.1, which encodes the sarco/endoplasmic reticulum calcium ATPase type 2 (SERCA2) ${ }^{6-10}$. SERCA2 is a member of a family of ion pumps, which maintain high calcium concentration in the endoplasmic reticulum ${ }^{1}$.

Many patients with mild disease require no treatment other than emollients, simple hygiene and advice to avoid sunburn. Topical tretinoin and isotretinoin, adapalene and tazarotene have been reported as effective but irritation is limiting factor and effect can be seen only in 3 months. Antiseptics may help infected plaques, which may respond to topical steroid/antibiotic combinations. For those with more severe disease, oral retinoids are usually effective; both acitretin and isotretinoin are used. Severe inflammatory exacerbations of Darier's disease occur in some patients, and may respond to ciclosporin; The use of biological agents has not been reported. Dermabrasion or laser treatment may prove useful, usually in limited areas. Benefit from photodynamic therapy, and with topical 5-fluorouracil in two patients has been reported ${ }^{1}$.

Amongst newer modalities, laser ablation of recalcitrant plaques has been reported in seven keratosis follicularis (Darier disease) patients. Of these, three patients were treated with carbon dioxide lasers ${ }^{4,5,6}$ with Er:YAG lasers ${ }^{7}$ and two with pulsed-dye lasers ${ }^{8}$. In all of these cases, treatment was successful, with only one patient developing disease recurrence in her axilla in seven months after treatment. Another report describes resolution of disease using $1550-\mathrm{nm}$ erbium-doped fractional fiber laser?.

Carbon dioxide laser ablation with adjunctive dermabrasion, curettage, and shave excision in various combinations has also been reported to cause disease remission for 8 months to 2 years $^{10}$.

Photodynamic therapy with 5-aminolevulinic acid was used to treat keratosis follicularis (Darier disease) 
lesions in 6 patients, with 4 patients showing sustained improvement or clearance for a follow-up period of 6 months to 3 years ${ }^{11,12}$.

Surgical excision of hypertrophic intertriginous keratosis follicularis has been described in one case report ${ }^{13}$.

\section{Conclusion}

In our case we started Isotretinoin, he showed marked improvement, so we continued the treatment with regular follow up.

Darier's disease is genetic disease with mild to severe presentation. Depending upon the severity of the presentation we can treat this condition with medication and other modalities like dermaabrasion or lasers.

\section{References}

1. Judge MR, Mclean WHI, Disorders of Keratinization; In : Rook's Text book of Dermatology, Vol-1 8th edition, Burns T, Breathnach S, cox N, Griffiths C, Black well publication 2010, 19.81-19.85Eighth edition Rook's text book of dermatology, volume1, 19.81

2. ISCN (1995). International System for human cytogenetic nomenclature. Mitelman F, editor. Basel: S. Karger, 1995

3. Hashimoto K, Fujiwara K, Harada M, Setoyama M, Eto $\mathrm{H}$. Junctional proteins of keratinocytes in Grover's disease, Hailey-Hailey's disease and Darier's disease. J Dermatol 1995;22:159-70.

4. Brown VL, Kelly SE, Burge SM, Walker NP. Extensive recalcitrant Darier disease successfully treated with laser ablation. Br J Dermatol. Jan 2010;162(1):227-9.

5. McElroy JA, Mehregan DA, Roenigk RK. Carbon dioxide laser vaporization of recalcitrant symptomatic plaques of Hailey-Hailey disease and Darier's disease. J Am Acad Dermatol. Nov 1990;23(5 Pt 1):893-7.

6. Minsue Chen T, Wanitphakdeedecha R, Nguyen TH. Carbon dioxide laser ablation and adjunctive destruction for Darier-White disease (keratosis follicularis). Dermatol Surg. Oct 2008;34(10):1431-4.

7. Beier C, Kaufmann R. Efficacy of erbium:YAG laser

ablation in Darier disease and Hailey-Hailey disease. Arch Dermatol. Apr 1999;135(4):423-7.

8. Roos S, Karsai S, Ockenfel HM, Raulin C. Successful treatment of Darier disease with the flashlamp-pumped pulsed-dye laser. Arch Dermatol. Aug 2008;144(8):10735..

9. Katz TM, Firoz BF, Goldberg LH, Friedman PM. Treatment of Darier's disease using a $1550 \mathrm{~nm}$ erbium doped fiber laser. Dermatol Surg. 2010;36:142-146.

10. Minsue Chen T, Wanitphakdeedecha R, Nguyen TH. Carbon dioxide laser ablation and adjunctive destruction for Darier-White disease (keratosis follicularis). Dermatol Surg. Oct 2008;34(10):1431-4.

11. Exadaktylou D, Kurwa HA, Calonje E, Barlow RJ. Treatment of Darier's disease with photodynamic therapy. Br J Dermatol. Sep 2003;149(3):606-10.

12. Avery HL, Hughes BR, Coley C, Cooper HL. Clinical improvement in Darier's disease with photodynamic therapy. Australas J Dermatol. Feb 2010;51(1):32-5.

13. Ahcan U, Dolenc-Voljc M, Zivec K, Zorman P, Jurcic V. The surgical treatment of hypertrophic intertriginous Darier's disease. J Plast Reconstr Aesthet Surg. Nov 2009;62(11):e442-6. 